\title{
Małgorzata Dworakowska
}

\section{DOCHODY UZUPEŁNIAJĄCE W BUDŻETACH GMIN W ŚWIETLE AKTYWNEGO POSZUKIWANIA RENTY}

\section{Wprowadzenie}

Samorząd terytorialny został reaktywowany w Polsce w 1990 roku i ograniczał się wówczas tylko do gmin ${ }^{1}$. Znany obecnie trójstopniowy podział terytorialny państwa istnieje od 1 stycznia 1999 roku, gdyż od tego dnia zaczęły dodatkowo funkcjonować powiaty i województwa ${ }^{2}$. Powołanie trzech poziomów podziału terytorialnego kraju służy decentralizacji zadań publicznych. Najwięcej takich zadań realizuje gmina, która posiada domniemanie kompetencji³. Wykonywanie przyznanych obowiązków za każdym razem wiąże się z koniecznością posiadania przez gminy, powiaty i województwa niezbędnych środków finansowych na ich realizację. Konstytucja Rzeczypospolitej Polskiej ${ }^{4}$ wskazuje, iż dochodami jednostek samorządu terytorialnego są ich dochody własne, subwencje ogólne oraz dotacje celowe z budżetu państwa ${ }^{5}$. Dochodami uzupełniającymi budżetu są te środki finansowe, które nie należą do kategorii dochodów własnych.

\footnotetext{
${ }^{1}$ Istotna jest tu data: 8 marca 1990 roku, kiedy została wydana ustawa o samorządzie terytorialnym, która powołała samorząd terytorialny na najniższym szczeblu. Faktyczne przywrócenie gmin nastąpiło natomiast z dniem wejścia w życie ww. ustawy, czyli 27 maja 1990 roku.

2 Zostały one powołane ustawą z dnia 5 czerwca 1998 r. o samorządzie powiatowym (tekst jedn. DzU 2001 nr 142 poz. 1592 z późn. zm.) oraz ustawą z dnia 5 czerwca 1998 r. o samorządzie wojewódzkim (tekst jedn. DzU $2001 \mathrm{nr} 142$ poz. 1590 z późn. zm.).

3 Katalog zadań własnych gmin ma charakter otwarty (nie jest więc wyczerpujący), co oznacza, że gdy pojawi się nowe zadanie publiczne o znaczeniu lokalnym, które nie zostanie przypisane do innych podmiotów, to leży ono w kompetencji najniższego szczebla samorządu. W ten sposób gmina jest podstawowym podmiotem w systemie zadań jednostek samorządu terytorialnego. Zadania realizowane przez powiat i województwo stanowią natomiast uzupełnienie tych wykonywanych przez gminy.

4 Konstytucja Rzeczypospolitej Polskiej z dnia 2 kwietnia 1997 r. (DzU nr 78 poz. 483 z późn. zm.), art. 167 ust. 2. Do jednostek samorządu terytorialnego odnosi się cały rozdział VII „Samorząd terytorialny”.

${ }^{5}$ Różnorodne i wydajne dochody własne każdej jednostki samorządu terytorialnego przyczyniają się do poprawiania jej niezależności finansowej oraz podnoszenia samodzielności funkcjonowania. Tylko ta kategoria dochodów nie wystarcza jednak na realizację wszystkich niezbędnych wydatków. Z tego też względu dochody własne muszą być powiększane o dochody uzupełniające o charakterze transferowym, tj. subwencje ogólne i dotacje celowe z budżetu państwa.
} 
Szczególną uwagę w tej pracy autorka poświęciła samorządom gminnym, które wykonują swoje zadania najbliżej obywateli, a więc mają najpełniej odpowiadać na potrzeby społeczności lokalnej, co jest możliwe tylko wtedy, gdy dysponują wystarczającymi środkami finansowymi. Chcąc zabezpieczać potrzeby mieszkańców w najwyższym stopniu, przedstawiciele władzy lokalnej muszą zabiegać o jak największe środki finansowe w ramach poszczególnych źródeł dochodów. Konieczność takich działań otwiera możliwość aktywnego poszukiwania renty przez gminy. Poszukiwanie renty w sposób aktywny jest stosowane głównie do opisu relacji między jednostkami prywatnymi a publicznymi. Poprzez analogię można posługiwać się tym pojęciem do charakterystyki relacji wewnątrz sektora publicznego.

Niniejsze opracowanie przedstawia charakterystykę dochodów uzupełniających w budżetach gmin w Polsce, pokazuje ich funkcjonowanie z uwzględnieniem rozwiązań prawnych $\mathrm{w}$ tym zakresie oraz praktykę w ich stosowaniu. Ponadto praca zawiera analizę wielkości udziałów subwencji ogólnych i dotacji celowych z budżetu państwa w strukturze dochodów gmin, a także płynące stąd wnioski. Rozważania te służą znalezieniu odpowiedzi na pytanie, czy samorządy gminne aktywnie poszukują renty w zakresie dochodów uzupełniających.

\section{Możliwości aktywnego poszukiwania renty przez gminy}

Gmina jest podstawową jednostką samorządu terytorialnego, która jako jedyna została bezpośrednio wymieniona w Konstytucji $\mathrm{RP}^{6}$. Wykonuje ona zadania publiczne w imieniu własnym i na własną odpowiedzialność. Każda z gmin posiada osobowość prawną, a samodzielność gminy podlega ochronie sądowej. Z punktu widzenia prawa gmina to wspólnota samorządowa (tworzą ją zawsze mieszkańcy gminy) oraz odpowiednie terytorium ${ }^{7}$.

Gmina jest podmiotem, który może uczestniczyć w poszukiwaniu renty. Renta ekonomiczna jest „[...] to dodatkowa wypłata, jaką otrzymuje dany czynnik produkcji, ponad dochód transferowy konieczny do skłonienia go do świadczenia swych usług właśnie w tym zastosowaniu".

${ }^{6}$ Konstytucja Rzeczypospolitej Polskiej z dnia 2 kwietnia, art. 164 ust. 1.

7 Ustawa z dnia 8 marca 1990 r. o samorządzie gminnym (tekst jedn. DzU 2001 nr 142 poz. 1591 z późn. $z m$.$) , art. 1-2.$

8 D. Begg, S. Fischer, R. Dornbusch, Mikroekonomia, Polskie Wydawnictwo Ekonomiczne, Warszawa 2007, s. 317. 
Aktywne poszukiwanie renty to inaczej pogoń na rentą. Zjawisko to ma długą historię, a jego korzenie sięgają narodzin instytucji państwa. Aktywne poszukiwanie renty jest działaniem zgodnym z prawem. Polega ono na ponoszeniu pewnych nakładów przez podmioty zainteresowane uzyskaniem ochronnej regulacji np. ze strony polityków, sędziów czy urzędników. Takie opłaty są więc zgodne z prawem. Narzędziami ochronnej regulacji są:

- pomoc publiczna, np. operacje na podatkach, kredytach, parabudżetach czy kapitale przedsiębiorstwa oraz dotacje,

- ochrona przed konkurencją krajową,

- ochrona przed konkurencją zagraniczną,

- normy techniczne,

- popieranie produkcji dóbr komplementarnych, a przeciwdziałanie produkcji substytutów.

Aktywnego poszukiwania renty, podobnie jak przestępczości, nie da się całkowicie wyeliminować. Można jedynie dążyć do jego ograniczenia, ale to ciągle jest niezwykle trudnym przedsięwzięciem . W pogoni za rentą mogą uczestniczyć różne podmioty - zarówno z sektora prywatnego, jak i publicznego. Najwięcej przejawów takiej działalności leży na linii relacji jednostek prywatnych z publicznymi. Powstające w obu obszarach grupy interesu będą podejmowały różnorodne działania, aby osiągnąć zaplanowane cele. Wewnątrz sektora publicznego są także możliwości aktywnego poszukiwania renty. Mogą one skutkować pojawianiem się lub pogłębianiem podległości niektórych jednostek publicznych wobec władzy centralnej.

Pogoń za rentą może istnieć na rynkach konkurencyjnych, gdzie jest „[...] racjonalnym zachowaniem ekonomicznym podmiotów dążących do maksymalizacji użyteczności” ${ }^{10}$. Poszukiwanie renty w sposób aktywny może być także podejmowane przez różne grupy interesów. Mogą więc pojawiać się np. egoistyczne interesy jednostek skupiające się na osiągnięciu pozycji monopolisty, który w porównaniu z przedsiębiorcą działającym na rynku konkurencyjnym będzie oferował mniejszą wielkość produkcji, żądając za nią wyższej ceny. Oznacza to więc ogólnospołeczne straty dobrobytu powiększone o przejętą przez monopolistę część renty konsumenta. „[...] Tracenie zasobów w procesie zabiegania o rentę monopolistyczną [...] nazywa się aktywnym poszukiwaniem renty"11.

9 S. Sztaba, Renty aktywne poszukiwanie, w: Ekonomia od A do Z. Encyklopedia podręczna, red. S. Sztaba, Wydawnictwa Akademickie i Profesjonalne Spółka z o.o., Warszawa 2007, s. 403-404.

${ }^{10}$ S. Sztaba, Aktywne poszukiwanie renty. Teoria. Przykłady historyczne. Przejawy w polskiej gospodarce lat dziewięćdziesiątych, Oficyna Wydawnicza SGH, Warszawa 2002, s. 34.

11 Ibidem, s. 34. 
Aktywne poszukiwanie renty wywołuje zarówno straty ogólnospołeczne, jak i szkody gospodarcze. Należy więc przeciwdziałać pogoni za rentą. Najbardziej zainteresowani ograniczaniem aktywnego poszukiwania renty są głównie konsumenci, gdyż oni ponoszą znaczne koszty takiego stanu. Ich straty są większe niż zyski monopolistów. To oznacza, że kupujący zyskaliby więcej na konkurencji niż monopoliści na jej ograniczeniu. Konsumenci są jednak liczną i dość rozproszoną grupą, a tym samym generują wysokie koszty realizacji wspólnych zadań ${ }^{12}$. Tym samym ich zbiorowe działanie staje się praktycznie niemożliwe. Politycy natomiast, mimo że są powołani do ochrony interesu społecznego, są zainteresowani współpracą z grupami interesu - nie można więc liczyć z ich strony na przeciwdziałanie aktywnemu poszukiwaniu renty. Podobnie sytuacja wygląda w odniesieniu do urzędników, którzy są bardziej skłonni zwiększać ochronną regulację na rzecz grup interesu, niż ją ograniczać. Taki stan rzeczy pokazuje, że w państwach demokratycznych brakuje podmiotów chroniących interes ogólnospołeczny ${ }^{13}$.

W gospodarce rynkowej podstawowym regulatorem procesów gospodarczych jest samoczynnie działający rynek. W XIX wieku natomiast funkcje gospodarcze państwa były maksymalnie ograniczone, sprowadzone wyłącznie do roli „stróża nocnego". Państwo miało zajmować się tylko zabezpieczeniem własności, zapewnieniem ładu i porządku publicznego oraz obroną przed agresją z zewnątrz. Dominacja w społeczeństwie poglądu, iż rynek jest złym regulatorem procesów gospodarczych, kształtuje korzystne warunki dla grup interesu aktywnie poszukujących renty. Uzyskanie regulacji ochronnej dla zainteresowanych podmiotów łatwiej tu przedstawić społeczeństwu jako pozytywne dla ogółu gospodarki ${ }^{14}$.

Współczesne wysoko rozwinięte państwa cechuje gospodarka mieszana z silnym interwencjonizmem państwowym, który oddziałuje także na aktywne poszukiwanie renty. Istota pogoni za rentą oraz interwencjonizmu państwowego jest taka sama i jest nią transfer dochodów ${ }^{15}$. Należy tu zauważyć, iż poprzez transfer pieniędzy budżety gmin są powiązane $\mathrm{z}$ budżetem państwa. To tworzy pole do pogoni za rentą także w sektorze publicznym. Samorządy gminne stają się tu więc grupą interesów, która dąży do uzyskania jak najlepszych warunków swego funkcjonowania.

Analiza aktywnego poszukiwania renty wywołuje także chęć pomiaru tego zjawiska. Wobec braku odpowiednich miar bezpośrednich, ciekawe jest zastosowanie

\footnotetext{
12 Dotyczy to zarówno wymiany informacji między konsumentami, jak i ich wspólnego porozumienia na rzecz podjęcia określonych działań.

13 S. Sztaba, Aktywne poszukiwanie..., op.cit., s. 37-39 oraz strona internetowa PWN Biznes: http:// biznes.pwn.pl/index.php? module=haslo\&id $=3967153$ (1.01.2012)

14 S. Sztaba, Aktywne poszukiwanie..., op.cit., s. 47 i 54.

15 Ibidem, s. 54, 58-60.
} 
miary pośredniej w postaci interpretacji wielkości indeksu wolności gospodarczej danego państwa. Badając aktywne poszukiwanie renty, należy pamiętać, że im większa wolność gospodarcza, tym mniejsze aktywne poszukiwanie renty ${ }^{16}$. W Rankingu Wolności Gospodarczej ocenie podlegają poszczególne państwa, biorąc pod uwagę swobodę gospodarczą, jaką pozostawiają swoim obywatelom. Ranking obejmuje obecnie 141 krajów, a ocenie podlegają 42 zmienne z pięciu obszarów:

- rozmiar obecności państwa w gospodarce,

- praworządność i ochrona praw własności,

- stan pieniądza w danym kraju oraz dostęp obywateli i firm do pieniądza w ogóle,

- wymiana gospodarcza z zagranicą,

- regulacje prawne dotyczące działalności przedsiębiorstw, rynku pracy i rynku kapitałowego ${ }^{17}$.

Rysunek 1. Wyniki Rankingu Wolności Gospodarczej dla Polski w latach 1985-2009

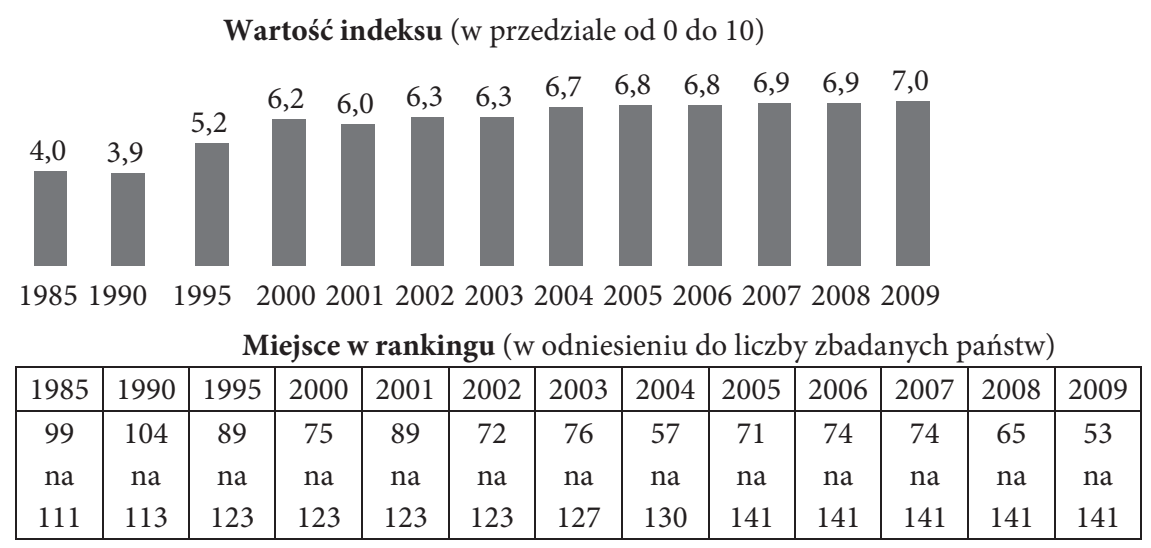

Źródło: Opracowanie własne na podstawie strony internetowej Economic Freedom Network prowadzonej przez Fraser Institute: http://www.freetheworld.com/cgi-bin/freetheworld/getinfo.cgi (1.01.2012).

W Rankingu Wolności Gospodarczej Polska podlega ocenie od 1985 roku (rysunek 1). Noty, które uzyskuje nasz kraj, mają charakter rosnący lub niezmienny w stosunku do roku wcześniejszego. Wyjątek stanowią tylko lata: 1990 (wynik o 0,1 punktu niższy niż pięć lat wcześniej) oraz 2001 (wynik niższy o 0,2 punktu niż rok wcześniej). W ostatniej edycji rankingu Polska z notą 7,0 punktów zajęła 53 miejsce i jest to najlepszy ze wszystkich dotychczasowych wyników. W naszym kraju jednak pogoń za rentą cały czas występuje. Dotyczy ona różnych grup interesu, np.

16 Ibidem, s. 62-64.

17 Strona internetowa Centrum Adama Smitha: http://www.smith.org.pl/pl/pages/display/35 (1.01.2012). 
przedsiębiorstw prywatnych poszukujących ochronnej regulacji. W badaniu tego zagadnienia ważne jest określenie, jaki jest udział samorządu terytorialnego w aktywnym poszukiwaniu renty, ale do żadnych danych statystycznych w tym obszarze nie udało się autorce dotrzeć.

Pogoń za rentą w gminach można przedstawiać w odniesieniu do kwestii gospodarki finansowej, a zwłaszcza do specyfiki funkcjonowania dochodów uzupełniających w budżetach gmin w naszym kraju. Taka forma aktywnego poszukiwania renty wynika z powiązania budżetów samorządów z budżetem państwa.

\section{Specyfika dochodów uzupełniających w budżetach gmin w Polsce}

Dochodami uzupełniającymi w budżetach gmin są subwencje ogólne i dotacje celowe $\mathrm{z}$ budżetu państwa. Stanowią one formę transferu środków finansowych $\mathrm{z}$ budżetu kraju do budżetów jednostek samorządu terytorialnego. Ich cechą charakterystyczną jest to, że nie są trwale oraz bezpośrednio powiązane z budżetem gminy, co ma miejsce w przypadku kategorii dochodów własnych ${ }^{18}$. Celem transferów pieniężnych jest uzupełnianie dochodów własnych oraz wyrównywanie kwot dochodów w przeliczeniu na jednego mieszkańca gminy ${ }^{19}$. Są one bardzo ważne dla ekonomicznie słabszych samorządów.

Obowiązujący podział na subwencje i dotacje wiąże się z rozróżnieniem na: środki pozostające w pełnej dyspozycji jednostki, która je otrzymała, oraz pieniądze mające być wydane wyłącznie na te cele, na które zostały przyznane ${ }^{20}$.

Rola dochodów uzupełniających jest dość szczególna, gdyż ze względu na duże dysproporcje w rozwoju społeczno-gospodarczym poszczególnych części naszego kraju oraz problematykę niskiego potencjału dochodowego samorządów dochody transferowe są niezwykle istotne dla funkcjonowania gmin. Różnice w rozwoju poszczególnych części kraju zależą m.in. od stopnia ich uprzemysłowienia, ale mogą mieć także swoje źródło $\mathrm{w}$ warunkach naturalnych związanych chociażby z położeniem geograficznym danej gminy oraz występowaniem na jej terenie surowców.

18 L. Patrzałek, Finanse samorzadu terytorialnego, Wydawnictwo Uniwersytetu Ekonomicznego we Wrocławiu, Wrocław 2010, s. 193.

19 J. Zarzecki, Solidarność społeczna w finansowaniu gminnego samorządu terytorialnego, w: Finansowanie gminnego samorzadu terytorialnego, red. D.A. Hałaburda, Wydawnictwa Wyższej Szkoły Ekonomicznej w Białymstoku, Białystok 2008, s. 37.

${ }^{20}$ H. Izdebski, Samorzad terytorialny. Podstawy ustroju i działalności, LexisNexis, Warszawa 2011, s. 313. 
Obserwowane zróżnicowania są więc często niezależne od mieszkającej na danym terenie ludności oraz przedstawicieli lokalnej władzy samorządowej. Trudniejsza sytuacja finansowa części gmin wynikająca z obiektywnych przyczyn ma być częściowo neutralizowana poprzez odpowiednie transfery środków finansowych z budżetu państwa na rzecz budżetów gmin.

Potrzeba istnienia tego typu transferów ma swoje źródła także w podejściu państwa, które zakłada utrzymanie minimalnego standardu usług publicznych o charakterze społecznym (np. oświata i opieka społeczna) świadczonych w poszczególnych częściach kraju, a finansowanych przez władze samorządowe. Ważne jest także niwelowanie różnic w poziomie rozwoju infrastruktury technicznej we wszystkich gminach, co często może być osiągane poprzez realizację odpowiednich projektów inwestycyjnych, których wykonanie zależy od posiadania przez gminy wymaganej kwoty środków finansowych.

Nie można jednak zapominać, że dochody uzupełniające w budżetach gmin mają też wady. Należy podkreślić, że przeważający udział transferów $\mathbf{z}$ budżetu państwa w strukturze dochodów ogółem uzależnia gminy od państwa. To oznacza, że taka jednostka samorządu terytorialnego mocniej reaguje na wszelkie zmiany, jakie zachodzą w sytuacji finansowej całego kraju w związku ze zmianą koniunktury gospodarczej. Stopień uzależnienia jest tym wyższy, im większy jest udział transferów, których przeznaczenie jest ustalane przez podmiot przekazujący środki. Wysoki udział transferów z budżetu państwa w ogólnej strukturze dochodów gmin świadczy również o niskiej samodzielności finansowej danej jednostki, a także ogranicza poczucie odpowiedzialności lokalnych polityków przed wyborcami za sytuację finansową gminy oraz zniechęca sprawujących władze do stymulowania rozwoju społeczno-gospodarczego. Istnienie transferów z budżetu państwa może więc rodzić przekonanie wśród przedstawicieli lokalnej władzy samorządowej, iż mogą ograniczać swoją działalność, bo gdy ich jednostki będą w gorszej sytuacji finansowej (np. nie będą generowały potrzebnych dochodów), uzyskają one wsparcie w postaci redystrybucji środków. Stosowanie subwencji i dotacji powoduje także konflikt z najbardziej efektywną, czyli rynkową alokacją kapitału ${ }^{21}$, co również jest wadą tego rodzaju przepływu pieniędzy.

Dochody uzupełniające budżetów gmin mogą być im przyznawane na różnej podstawie. Leszek Patrzałek wyodrębnia tu kryteria ${ }^{22}$ :

- uznaniowe - przyznanie środków finansowych zależy od subiektywnej decyzji podmiotu przekazującego pieniądze;

21 P. Swianiewicz, Finanse samorzadowe. Koncepcje, realizacja, polityki lokalne, Wydawnictwo Municypium SA, Warszawa 2011, s. 85.

22 L. Patrzałek, op.cit., s. 198-200. 
- zobiektywizowane, czyli mierzalne - mogą one uwzględniać wskaźniki charakteryzujące sytuację społeczno-gospodarczą gminy, kluczowe dla podjęcia decyzji o przyznaniu środków;

- mieszane - obejmujące zarówno elementy uznaniowe, jak i obiektywne.

Najlepiej byłoby, aby jak największa część dochodów uzupełniających była przyznawana na podstawie obiektywnych kryteriów. Tylko pozbawione uznaniowości decyzje podmiotu przekazującego środki są w stanie tworzyć przejrzyste warunki funkcjonowania samorządów gminnych oraz ograniczać ich udział w pogoni za rentą.

W strukturze dochodów ogółu gmin w Polsce w latach 2006-2011 widać przewagę dochodów uzupełniających nad dochodami własnymi (rysunek 2). W żadnym $\mathrm{z}$ analizowanych lat dochody własne nie przekroczyły połowy środków finansowych budżetu. W każdym roku ich wielkość była jednak powyżej $40 \%$.

\section{Rysunek 2. Struktura dochodów gmin w latach 2006-2011 (w \%)}

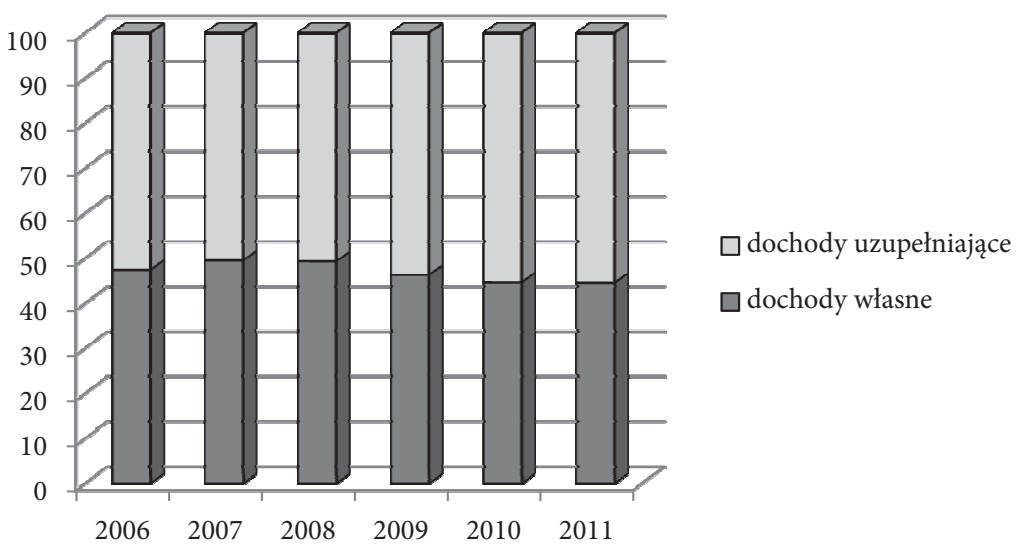

Uwaga: Dane dotyczące 2011 roku obejmują jedynie trzy kwartały.

Źródło: Opracowanie własne na podstawie danych ze strony internetowej Ministerstwa Finansów: http://www. mf.gov.pl/_files_/finanse_samorzadow/sprawozdania_budzetowe/2006/sprawozdanie_2006.pdf, http://www. mf.gov.pl/_files_/finanse_samorzadow/sprawozdania_budzetowe/2007/sprawozdanie_2007.pdf, http://www. mf.gov.pl/_files_/finanse_samorzadow/sprawozdania_budzetowe/2008/jst_sprawozdanie2008.pdf, http:// www.mf.gov.pl/_files_/finanse_samorzadow/sprawozdania_budzetowe/2009/jst_spraw2009.pdf, http://www. $\mathrm{mf} . g o v . p l /$ files_/finanse_samorzadow/sprawozdania_budzetowe/2010/jst_sprawozdanie2010.pdf, http://www. mf.gov.pl/_files_/finanse_samorzadow/sprawozdania_budzetowe/2011/kw3/gminy_iiikw11_dw.xls (1.01.2012).

Mimo że subwencje ogólne i dotacje celowe z budżetu państwa określamy wspólnym mianem dochodów uzupełniających budżety gmin, warto znać specyfikę obu tych transferów (tabela 1). 
Tabela 1. Różnice między subwencjami ogólnymi a dotacjami celowymi

\begin{tabular}{|l|l|}
\hline \multicolumn{1}{|c|}{ Subwencje ogólne } & \multicolumn{1}{|c|}{ Dotacje celowe } \\
\hline $\begin{array}{l}\text { O sposobie wydatkowania środków decyduje jednostka } \\
\text { samorządu terytorialnego. }\end{array}$ & $\begin{array}{l}\text { Środki przeznaczone na zadania dokładnie określone } \\
\text { przez podmiot dotujący. }\end{array}$ \\
\hline Kryteria ich przyznawania są obiektywne. & $\begin{array}{l}\text { Kryteria ich przyznawania są uznaniowe. Kalkulacja } \\
\text { kwot na podstawie podobnych zadań finansowanych } \\
\text { z budżetu państwa. }\end{array}$ \\
\hline Pełnią funkcję wyrównującą dochody. & $\begin{array}{l}\text { Przyznawane bez względu na potencjał dochodowy } \\
\text { jednostki. }\end{array}$ \\
\hline $\begin{array}{l}\text { Pełnią funkcję motywacyjną, gdyż wyrównanie nie jest } \\
\text { pełne. }\end{array}$ & $\begin{array}{l}\text { Kwota dotacji na zadania z zakresu administracji } \\
\text { rządowej oraz inne zadania zlecone ustawami powinna } \\
\text { pokryć całość wydatków niezbędnych na ich } \\
\text { realizację. }\end{array}$ \\
\hline $\begin{array}{l}\text { Nie podlegają zwrotowi bez względu na stopień } \\
\text { wykonania zadań. }\end{array}$ & $\begin{array}{l}\text { Zwracane w części odpowiadającej niezrealizowanym } \\
\text { zadaniom. }\end{array}$ \\
\hline $\begin{array}{l}\text { Wykorzystanie środków podlega kontroli jedynie pod } \\
\text { względem legalności. }\end{array}$ & $\begin{array}{l}\text { Wykorzystanie środków podlega kontroli pod względem } \\
\text { legalności, celowości, rzetelności i gospodarności. }\end{array}$ \\
\hline
\end{tabular}

Źródło: Opracowanie własne na podstawie A. Miszczuk, M. Miszczuk, K. Żuk, Gospodarka samorządu terytorialnego, Wydawnictwo Naukowe PWN, Warszawa 2007, s. 86.

Wysokość i wzajemne relacje poszczególnych źródeł dochodów informują o zakresie uzależnienia budżetu gminy od pieniędzy transferowych oraz pomagają pozyskać wiedzę o stopniu samodzielności dochodowej badanej jednostki. Szczegółowa analiza źródeł dochodów gmin w latach 2006-2011 (tabela 2) wskazuje, iż we wszystkich analizowanych latach żadne z trzech źródeł dochodów nie miało udziału przekraczającego 50\%. Najbliżej tej granicy znalazły się dochody własne, których udział w strukturze dochodów gmin był na poziomie od 44,5\% (pamiętając, że dane dotyczące 2011 roku nie obejmują ostatniego kwartału) do 49,5\% (w 2007 roku). Wśród dochodów uzupełniających w każdym z analizowanych lat dominowały subwencje ogólne nad dotacjami, co należy ocenić pozytywnie ${ }^{23}$. Udział subwencji ogólnej w strukturze dochodów gmin wynosił od 31,3\% (w 2007 roku) do 33,9\% (w 2009 roku). Najmniejsze znaczenie w przedstawionym zestawieniu mają natomiast dotacje, których udział osiągnął maksymalnie 24\% w 2010 roku.

Analizując strukturę dochodów budżetowych gmin, należy pamiętać, że dotychczas nie udało się stworzyć takiego systemu rozdzielania dochodów publicznych, aby każda jednostka samorządu terytorialnego mogła działać na zasadzie samofinansowania ${ }^{24}$, a więc bez konieczności korzystania $\mathrm{z}$ dochodów

${ }_{23}$ Szerzej na ten temat w punktach 2.1 i 2.2, gdzie została przedstawiona specyfika pozyskiwania środków w ramach obu transferów.

${ }_{24}$ Cz. Rudzka-Lorentz, H. Sochacka-Krysiak, Źródła finansowania lokalnych zadań publicznych a problem samodzielności jednostek samorządu terytorialnego, w: Gospodarka finansowa jednostek 
uzupełniających. Warto jednak za każdym razem zestawiać, na przestrzeni lat, wielkości różnych typów dochodów ze sobą oraz wyciągać płynące stąd wnioski. Korzystając $\mathrm{z}$ danych zawartych $\mathrm{w}$ tabeli 2, można porównać strukturę dochodów gmin z lat 2010 i 2006. Takie zestawienie pozwala zauważyć spadek udziału dochodów własnych o 2,8\% oraz zmniejszenie się o 1,2\% subwencji ogólnych, a także wzrost znaczenia dotacji w całkowitej strukturze dochodów. Zaobserwowane zjawiska należy oceniać negatywnie z punktu widzenia finansów samorządowych. Wzrost udziału dotacji jest wprawdzie związany z nałożeniem na gminy nowych zadań, może jednak także sugerować próby aktywnego poszukiwania renty w tym obszarze działania tej jednostki.

Tabela 2. Źródła dochodów gmin w latach 2006-2011 (w \%)

\begin{tabular}{|l|c|c|c|c|c|c|}
\hline \multirow{2}{*}{ Źródło dochodów } & \multicolumn{7}{|c|}{ Rok } \\
\cline { 2 - 7 } & 2006 & 2007 & 2008 & 2009 & 2010 & $2011^{\text {a }}$ \\
\hline Dochody własne & 47,4 & 49,5 & 49,3 & 46,3 & 44,6 & 44,5 \\
\hline Dotacje celowe & 20,0 & 19,2 & 18,8 & $19,8^{\mathrm{b}}$ & $24,0^{\mathrm{b}}$ & $21,7^{\mathrm{b}}$ \\
\hline Subwencje ogólne & 32,6 & 31,3 & 31,9 & 33,9 & 31,4 & 33,8 \\
\hline
\end{tabular}

${ }^{a}$ Dane dotyczą trzech kwartałów 2011 roku.

${ }^{\mathrm{b}}$ Udział dotacji ogółem w dochodach gmin.

Źródło: Opracowanie własne na podstawie danych ze strony internetowej Ministerstwa Finansów: http://www. mf.gov.pl/_files_/finanse_samorzadow/sprawozdania_budzetowe/2006/sprawozdanie_2006.pdf, http://www. mf.gov.pl/_files_/finanse_samorzadow/sprawozdania_budzetowe/2007/sprawozdanie_2007.pdf, http://www. mf.gov.pl/_files_/finanse_samorzadow/sprawozdania_budzetowe/2008/jst_sprawozdanie2008.pdf, http:// www.mf.gov.pl/_files_/finanse_samorzadow/sprawozdania_budzetowe/2009/jst_spraw2009.pdf, http://www. mf.gov.pl/_files_/finanse_samorzadow/sprawozdania_budzetowe/2010/jst_sprawozdanie2010.pdf, http://www. mf.gov.pl/_files_/finanse_samorzadow/sprawozdania_budzetowe/2011/kw3/gminy_iiikw11_dw.xls (1.01.2012).

Znając strukturę dochodów gmin oraz specyfikę występujących tu transferów z budżetu państwa, należy zauważyć, że jednostki samorządu terytorialnego najniższego szczebla jako grupy interesu mogą uczestniczyć w aktywnym poszukiwaniu renty. Ich działalność może dotyczyć oddziaływania na etapie tworzenia lub zmiany konstrukcji prawnych regulujących możliwości otrzymania przez samorząd pieniędzy $z$ budżetu państwa, jak również obejmować bezpośredni wpływ na podmioty przyznające środki według subiektywnych kryteriów. Poznaniu konkretnych możliwości pogoni za rentą w gminach posłuży przedstawienie szczegółowych uregulowań w zakresie funkcjonowania dwóch źródeł ich dochodów, jakimi są subwencje ogólne i dotacje celowe z budżetu państwa.

samorzadu terytorialnego $w$ warunkach decentralizacji zarzadzania sektorem publicznym, red. H. Sochacka-Krysiak, Oficyna Wydawnicza SGH, Warszawa 2008, s. 148. 


\subsection{Subwencje ogólne w budżetach samorządów gminnych}

Termin „subwencja” pochodzi z języka łacińskiego i oznacza pomoc finansową o charakterze bezzwrotnym, która może być przyznawana różnym podmiotom.

Subwencja ogólna dla gmin jest jednym z trzech źródeł dochodów budżetów lokalnych. Stanowi ona obligatoryjną formę transferu zasobów finansowych z budżetu państwa na rzecz gminy, który odbywa się według zobiektywizowanych kryteriów. Przekazane w ten sposób środki mają zazwyczaj służyć równoważeniu budżetu jednostki. Celem istnienia subwencji ogólnej jest zarówno wyrównywanie różnic dochodowych między poszczególnymi gminami, jak i powiększanie ilości środków finansowych, którymi samorządy mogą dysponować. Istotną funkcją subwencji jest także finansowanie zadań o charakterze oświatowym ${ }^{25}$. Należy podkreślić, iż o przeznaczeniu pieniędzy otrzymanych z tytułu subwencji ogólnej decyduje organ stanowiący gminy, który ma dowolność w wydatkowaniu tych środków. Taka sytuacja jest pozytywna, gdyż nie ogranicza samodzielności samorządu. Ze względu na swoją specyfikę subwencja ogólna w niektórych państwach jest określana mianem „dotacji ogólnej”26.

Dla gospodarki finansowej gmin ważny jest fakt, że w budżecie państwa nie można zablokować wydatków na subwencje ogólne nawet w sytuacji zagrożenia realizacji ustawy budżetowej ${ }^{27}$. Taki stan oznacza, że subwencje są dla gmin środkami gwarantowanymi, a to będzie rodzić chęć pozyskania tych pieniędzy w jak największej ilości.

Pokaźne subwencje ogólne zniechęcają władze lokalne do podejmowania działań powiększających samodzielne dochody gmin, a koncentrują ich uwagę na pozyskiwaniu jak największych kwot subwencji. W ten sposób może rodzić się „roszczeniowa” postawa gmin wobec państwa, zainteresowanych zwiększaniem wydatków budżetu państwa na subwencję ogólną ${ }^{28}$. Jest to obszar zależności, w którym aktywne poszukiwanie renty przez gminy będzie występować.

Subwencja ogólna dla gmin składa się z trzech części: wyrównawczej, równoważącej i oświatowej (rysunek 3). Części te nie są jednak jednorodne, biorąc pod

25 J. Sierak, R. Górniak, Ocena efektywności i finansowania projektów inwestycyjnych jednostek samorządu terytorialnego współfinansowanych funduszami Unii Europejskiej, Oficyna Wydawnicza SGH, Warszawa 2011, s. 38-39.

26 P. Swianiewicz, op.cit., s. 32.

27 E. Kornberger-Sokołowska, J. Zdanukiewicz, R. Cieślak, Jednostki samorządu terytorialnego jako beneficjenci środków europejskich, Oficyna Wolters Kluwer, Warszawa 2010, s. 62.

28 E. Kornberger-Sokołowska, Budżet państwa a budżety jednostek samorzadu terytorialnego, w: Stan i kierunki rozwoju finansów samorządu terytorialnego, red. L. Patrzałek, Wydawnictwa Wyższej Szkoły Bankowej, Poznań-Wrocław 2007, s. 40-41. 
uwagę aspekty prawno-finansowe. Łącznie tworzą skomplikowany system zasilania budżetów gmin, którego skonstruowanie w pewnych przypadkach było wynikiem nacisków politycznych związanych z dążeniem części gmin do powiększenia kwot pieniędzy uzyskiwanych dzięki subwencjom. Konkretnym przykładem takiego zjawiska są wyznaczniki przyznawania subwencji ogólnych na rzecz gmin wiejskich oraz dużych miast ${ }^{29}$. To wszystko świadczy więc o tym, iż pogoń za rentą ze strony samorządu na etapie samego przygotowywania rozwiązań prawnych w zakresie uregulowania kryteriów przyznawania subwencji ogólnych istniała. Spowodowała ona powstanie nie w pełni konsekwentnego systemu subwencjonowania gmin, który preferuje określone kategorie samorządów i do nich kieruje większe wsparcie finansowe.

Rysunek 3. Podział subwencji ogólnej dla gmin

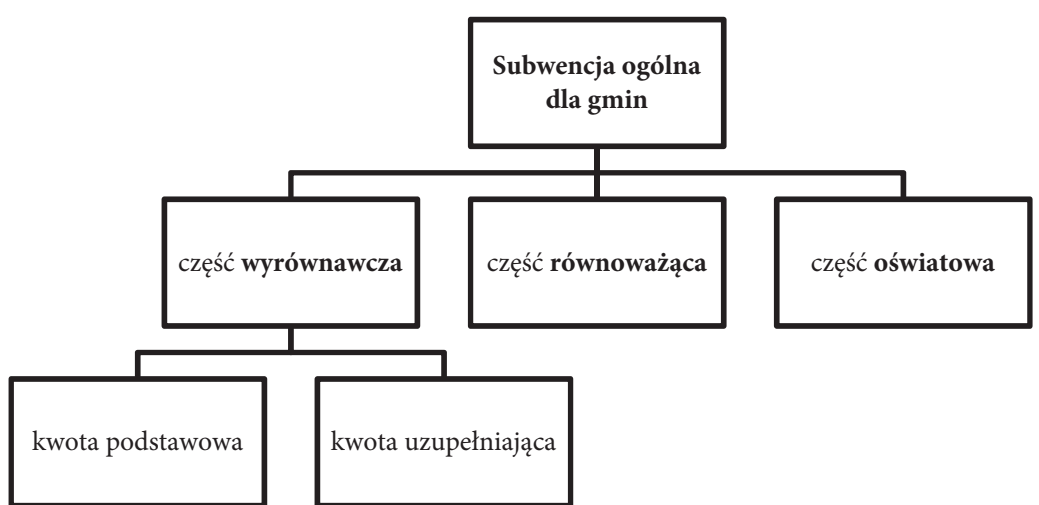

Źródło: Opracowanie własne na podstawie ustawy z dnia 13 listopada 2003 r. o dochodach jednostek samorządu terytorialnego (tekst jedn. DzU $2010 \mathrm{nr} 80$ poz. 526 z późn. zm.), art. 7 ust. 1.

Należy jednak zauważyć, że w ramach istniejących rozwiązań dotyczących subwencjonowania gmin określone zostały w sposób mierzalny warunki otrzymania środków finansowych w każdej z trzech części subwencji ogólnej. Czytelne zapisy ustawy ${ }^{30}$ powodują, iż w zakresie ostatecznie przyjętych zasad subwencjonowania samorządu nie występują arbitralne decyzje urzędników administracji rządowej ${ }^{31}$. Kwoty przeznaczone na poszczególne części subwencji ogólnej są określone w ustawie budżetowej. Są one przekazywane gminom w dwunastu miesięcznych ratach.

Część wyrównawcza subwencji ogólnej dla gmin jest finansowana w całości ze środków budżetu państwa. Jej specyfika zapewnia pionową redystrybucję środków

\footnotetext{
${ }^{29}$ E. Kornberger-Sokołowska, J. Zdanukiewicz, R. Cieślak, op.cit., s. 63.

30 Ustawa z dnia 13 listopada 2003 r. o dochodach jednostek samorządu terytorialnego (tekst jedn. DzU $2010 \mathrm{nr} 80$ poz. 526 z późn. zm.), art. 19-32.

${ }^{31}$ L. Patrzałek, op.cit., s. 201.
} 
publicznych. Część wyrównawcza składa się z kwoty podstawowej oraz kwoty uzupełniającej (rysunek 3):

- Kwotę podstawową otrzymują te gminy, w których wskaźnik dochodów podatkowych na jednego mieszkańca jest mniejszy niż 92\% wskaźnika dochodów podatkowych dla wszystkich gmin w kraju ${ }^{32}$. Taka konstrukcja tej kwoty służy wspieraniu gmin ekonomicznie słabszych.

- Kwota uzupełniająca przysługuje tym gminom, w których gęstość zaludnienia jest niższa od średniej gęstości zaludnienia w kraju. Wyjątek stanowi tu jedynie sytuacja, w której wskaźnik dochodów podatkowych na jednego mieszkańca w słabo zaludnionej gminie jest wyższy od 150\% wskaźnika dochodów podatkowych dla wszystkich gmin w kraju, gdyż to oznacza brak możliwości skorzystania takiej gminy z kwoty uzupełniającej. Wówczas niewypłacone bogatej gminie środki zwiększają część równoważącą subwencji ogólnej dla gmin.

Część równoważąca subwencji ogólnej dla gmin powstaje natomiast $\mathrm{z}$ wpłat gmin silniejszych finansowo. Stanowi ona sumę:

- wpłat gmin, w których wskaźnik dochodów podatkowych na jednego mieszkańca jest wyższy od 150\% wskaźnika dochodów podatkowych dla wszystkich gmin w kraju;

- łącznej kwoty uzupełniającej części wyrównawczej subwencji ogólnej, której nie uzyskały gminy ze względu na przekroczenie progu dochodów podatkowych na jednego mieszkańca.

Takie źródła finansowania tej części subwencji ogólnej oznaczają redystrybucję poziomą między gminami w całym kraju. Budżet państwa pełni tu rolę pośrednika - zbiera pieniądze od gmin bogatszych i przekazuje je biedniejszym. Podstawę do wykonania wszelkich obliczeń stanowią kwoty dla roku poprzedzającego rok bazowy (np. dla roku 2012 punktem odniesienia jest 2010 rok). Część równoważącą subwencji ogólnej dzieli się w następujący sposób:

- połowę kwoty rozdziela się między uprawnione gminy miejskie, a kolejne $25 \%$ sumy między uprawnione gminy wiejskie i miejsko-wiejskie w związku z realizowanymi w nich wydatkami na dodatki mieszkaniowe;

- 25\% kwoty rozdziela się między gminy wiejskie i miejsko-wiejskie, w których udziały we wpływach z podatku dochodowego od osób fizycznych oraz dochody z podatku rolnego i leśnego w przeliczeniu na jednego mieszkańca gminy są niższe od ustalonego limitu.

32 Do dochodów podatkowych wlicza się łączną kwotę wpływów z tytułu podatków: od nieruchomości, rolnego, leśnego, od środków transportowych, od czynności cywilnoprawnych, od osób fizycznych opłacanego w formie karty podatkowej oraz wpływy z opłat: skarbowej i eksploatacyjnej, a także udziały we wpływach z podatku dochodowego od osób fizycznych i od osób prawnych. 
Gminy, które uzyskują pieniądze w ramach subwencji równoważącej, mogą je dowolnie wydawać, nie muszą więc przeznaczać tych środków na ważne dla społeczności lokalnej działania. Skutek jest więc taki, że gmina, która otrzymała wsparcie, może je przeznaczyć na wydatki bieżące. Natomiast gmina bogatsza, która musiała oddać pieniądze na rzecz uboższej, wydałaby te środki zapewne na działalność inwestycyjną, która poprawia warunki życia ludności oraz przyczynia się do rozwoju społeczno-gospodarczego kraju.

Andrzej Borodo proponuje, aby subwencję równoważącą zastąpić subwencją inwestycyjną, a pozyskiwane $\mathrm{w}$ ten sposób przez biedniejsze samorządy pieniądze przeznaczać na finansowanie ich zadań inwestycyjnych ${ }^{33}$.

Wysokość części oświatowej subwencji ogólnej dla samorządów ustalana jest corocznie w ustawie budżetowej, przy czym wielkość ta w każdym kolejnym roku nie może być mniejsza niż w roku bazowym. Dodatkowo jest zawsze korygowana o kwotę wydatków z tytułu zmiany realizowanych zadań oświatowych. Mimo że nazwa tej części subwencji ogólnej może sugerować konieczność jej przeznaczenia na zadania oświatowe realizowane przez gminy, to w rzeczywistości nie ma to związku $\mathrm{z}$ faktycznie ponoszonymi na ten cel wydatkami.

W samej ustawie nie ma szczegółowego sposobu kalkulacji kwot przysługujących poszczególnym gminom z tytułu tej części subwencji ogólnej i oznacza to konieczność oczekiwania na określenie każdorocznych uregulowań w tym zakresie. Taka sytuacja powoduje brak stabilności finansowej gmin w kilkuletniej perspektywie.

Metoda podziału subwencji oświatowej jest wynikiem ustaleń, które w każdym roku zapadają w Komisji Wspólnej Rządu i Samorządu Terytorialnego, gdzie przedstawiciele poszczególnych typów jednostek samorządu terytorialnego próbują wpływać na ostateczne kryteria podziału, aby uzyskać korzystny dla nich sposób podziału środków i jak najlepiej realizować interesy samorządów, które reprezentują ${ }^{34}$. Potwierdza to więc, że gminy tu także uczestniczą w pogoni za rentą.

W 2010 roku na rachunki wszystkich gmin w Polsce z tytułu subwencji ogólnej przekazano łącznie kwotę prawie 23 mld zł. Szczegółowy udział procentowy poszczególnych typów subwencji w wielkości zbiorczej obrazuje rysunek 4 . Podstawowe znaczenie miała tu część oświatowa. Ze względu na jej wielkość, przyjmowane sposoby podziału środków mają ogromną wagę dla sytuacji finansowej gmin. Obecny stan prawny tworzy możliwość corocznego aktywnego poszukiwania renty w odniesieniu do subwencji oświatowej, z czego zainteresowane samorządy chętnie

33 A. Borodo, System finansowy samorządu terytorialnego w Polsce, Wydawnictwo „Dom Organizatora”, Toruń 2011, s. 147.

34 P. Swianiewicz, op.cit., s. 119. 
korzystają. Ponad jedną czwartą całości kwoty subwencji ogólnej w 2010 roku zajmowała część wyrównawcza. Najmniejszy udział miała natomiast część równoważąca subwencji ogólnej, ale dla tych gmin, które przekazują środki, jest to wydatek mocno obciążający budżet.

Rysunek 4. Struktura otrzymanej przez gminy subwencji ogólnej w 2010 roku (w \%)

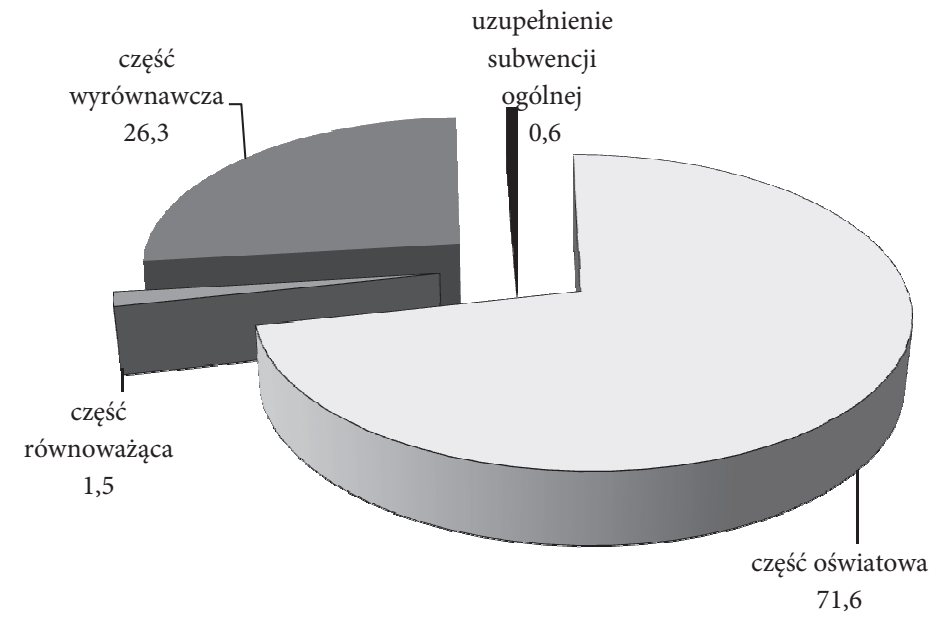

Źródło: Opracowanie własne na podstawie danych ze strony internetowej Ministerstwa Finansów: http:// www.mf.gov.pl/_files_/finanse_samorzadow/sprawozdania_budzetowe/2010/2010kw4/gminy_ivkw10_dw.xls (2.01.2012).

Wśród przedstawionych rodzajów subwencji ogólnej najwięcej kontrowersji budzi subwencja równoważąca. Według założeń ma ona służyć zapewnieniu podobnych warunków życia w różnych częściach kraju. Specyfika jej funkcjonowania jest jednak trudna do jednoznacznej oceny, ale pozwala na aktywne poszukiwanie renty przez gminy.

Ten typ subwencji jest bardzo często nazywany „janosikowym” i łączy się ze swego rodzaju karaniem bardziej gospodarnych gmin, które posiadają wydajne źródła dochodów. Należy jednak pamiętać, iż nie tylko gospodarność wpływa na sytuację ekonomiczną samorządów. Niejednokrotnie zdarza się więc, że gorsza sytuacja finansowa gminy jest wynikiem niezależnych od niej okoliczności związanych chociażby $\mathrm{z}$ położeniem jednostki ${ }^{35}$.

35 B. Kołaczkowski, M. Ratajczak, Gospodarka finansowa samorzadu terytorialnego w Polsce, Oficyna Wolters Kluwer, Warszawa 2010, s. 118. 
Wokół istoty funkcjonowania subwencji równoważącej odbywają się obecnie ożywione dyskusje. Wyraźną niechęć do takiego sposobu finansowania wykazują gminy bogate, które muszą przekazywać część zrealizowanych dochodów własnych na rzecz gmin biedniejszych ${ }^{36}$.

Potrzebę zmian ustawowych w tym zakresie widzą nie tylko osoby sprawujące władze w jednostkach samorządu terytorialnego, które muszą oddawać środki, ale także ich mieszkańcy. Poparcie społeczne zyskał projekt ustawy dotyczący zmian w janosikowym. W sierpniu 2011 roku został on złożony marszałkowi sejmu wraz ze 155 tys. podpisów. Przedstawiona w nim nowelizacja ustawy o dochodach jednostek samorządu terytorialnego ${ }^{37}$ nie zlikwiduje subwencji równoważącej, ale zredukuje janosikowe o $20 \%$ oraz zmieni zasady jego naliczania i przyznawania. Takie rozwiązanie oznacza większe środki, skierowane najczęściej na działania inwestycyjne, w samorządach przekazujących pieniądze uboższym jednostkom. Pozostałe $80 \%$ tej części subwencji ogólnej miałoby być przeznaczone dla biedniejszych jednostek, które przedstawią projekt realizacji konkretnego działania i zostanie on wybrany w konkursie. Oznacza to możliwość wspierania wybranych samorządów w urzeczywistnianiu określonych celów.

Sceptycznie do przedstawionej próby zmiany prawa odnosi się Ministerstwo Finansów, a negatywne nastawienie ma Związek Gmin Wiejskich $\mathrm{RP}^{38}$.

Gminy o ponadprzeciętnych dochodach, płacące na rzecz uboższych jednostek często pokaźne sumy pieniędzy, dążą do takich zmian prawa, aby polepszyć warunki swego funkcjonowania. Oznaczać to jednak będzie pogorszenie sytuacji jednostek biedniejszych. W ten sposób powstają dwie ścierające się grupy zainteresowane innymi rozwiązaniami ustawowymi. Każda z nich stara się przekonać do swojego stanowiska, aby jak najlepiej zabezpieczyć interes reprezentowanej jednostki. Zarówno bogatsze, jak i biedniejsze gminy uczestniczą więc w aktywnym poszukiwaniu renty.

Konieczność zmian w zakresie funkcjonowania części równoważącej subwencji ogólnej jest widoczna. Jeśli zmiany zostałyby wprowadzone w kształcie przedstawionym w obywatelskim projekcie ustawy, to niezmiernie ważne byłoby określenie obiektywnych kryteriów wyboru konkretnych działań objętych finansowaniem przez środki pochodzące od bogatszych samorządów. Jest to tak istotne, gdyż konkursy

\footnotetext{
36 J. Sierak, R. Górniak, op.cit., s. 40.

37 Strona internetowa inicjatywy na rzecz zmniejszenia podatku janosikowego: http://www.stop janosikowe.pl/ (6.01.2012). Strona zawiera m.in. projekt ustawy obywatelskiej oraz informacje związane $\mathrm{z}$ całą akcją, które były przedstawiane w mediach.

38 F. Grabowski, Co dalej z „janosikowym”, „Pismo Samorządu Terytorialnego Wspólnota” nr 37, 2011, s. 59.
} 
oparte na subiektywnych kryteriach mogą jeszcze bardziej powiększyć obszar, w którym gminy uczestniczą w pogoni za rentą.

Obecny stan regulacji subwencji ogólnej pozwala na aktywne poszukiwanie renty przez samorządy. Właściwe byłoby stworzenie takiego systemu, który nie faworyzowałby w zasilaniu subwencyjnym określonych typów gmin, ale wydaje się to zadaniem zbyt trudnym do osiągnięcia ze względu na dążenia różnych typów samorządów terytorialnych do jak największego dla nich dostępu do transferów z budżetu państwa o charakterze ogólnym. Pożądane byłoby także przygotowanie takich regulacji prawnych w zakresie przyznawania subwencji ogólnych, aby gminy mogły właściwie szacować wielkość środków przypadających z tego źródła w kolejnych latach. Ważne jest również kształtowanie obiektywnych kryteriów udzielania wsparcia. Zrealizowanie przedstawionych postulatów minimalizowałoby uczestnictwo gmin $\mathrm{w}$ pogoni za rentą.

\subsection{Dotacje celowe $z$ budżetu państwa jako źródło finansowania gmin}

Dotacje celowe są drugą formą transferu dochodów z budżetu państwa. Charakteryzują się one tym, że są przeznaczane na realizację konkretnego zadania publicznego. Środki te są przyznawane na podstawie subiektywnej decyzji podmiotu dotującego i muszą być wydatkowane w sposób ściśle przez niego określony. Samorządy gminne będą więc zainteresowane pozyskiwaniem tu jak największych pieniędzy. To stwarza możliwości aktywnego poszukiwania renty przez gminy ubiegające się o taki typ wsparcia.

Sposób podziału dotacji pokazuje, iż państwo wpływa na wydatki gmin i tym samym ogranicza samodzielność ich działania. Uwzględniając fakt, że gminy są największym beneficjentem dotacji rządowych, to ich uzależnienie od budżetu centralnego jest znaczące ${ }^{39}$. Uznaniowość w rozdzielaniu dotacji celowych często oznacza dowolność ich przyznawania przez państwo. Może to sugerować chęć przekazania środków finansowych konkretnym gminom i ich faworyzowanie na tle innych jednostek samorządu terytorialnego.

Paweł Swianiewicz zauważa, że „dotacje celowe są bardziej narażone na polityczne manipulacje $w$ procesie alokacji środków między poszczególne

39 J. Sierak, Sytuacja finansowa jednostek samorzadu terytorialnego w Polsce w latach 2004-2009, w: Fundusze Unii Europejskiej jako źródło finansowania rozwoju infrastruktury komunalnej w Polsce, red. J. Sierak, Oficyna Wydawnicza SGH, Warszawa 2010, s. 112-113. 
samorządy"40 . To sprzyja pogoni za rentą między gminami oraz ich dążeniu do pozyskiwania jak największych funduszy w ramach tej kategorii dochodów.

Wykaz możliwych dotacji celowych z budżetu państwa na rzecz gminy obejmuje środki przeznaczane na:

- finansowanie lub dofinansowanie zadań własnych,

- zadania realizowane przez gminy na podstawie porozumień zawartych z organami administracji rządowej,

- zadania z zakresu administracji rządowej oraz na inne zadania zlecone ustawami,

- realizację zadań wynikających z umów międzynarodowych,

- usuwanie bezpośrednich zagrożeń dla bezpieczeństwa i porządku publicznego, skutków powodzi i osuwisk ziemnych oraz skutków innych klęsk żywiołowych ${ }^{41}$.

Zakłada się tu, że dotacje celowe służą wykonaniu przez władze samorządowe określonych zadań, które są także ważne z punktu widzenia ogólnych interesów państwa ${ }^{42}$.

Jeżeli zadanie, na którego realizację przyznano dotację celową, nie zostanie wykonane, to przekazane środki w części, w jakiej zadanie nie zostało zrealizowane, podlegają zwrotowi do budżetu państwa ${ }^{43}$. Dotacje wykorzystane niezgodnie z przeznaczeniem, a także pobrane nienależnie lub w nadmiernej wysokości są oddawane do budżetu państwa wraz z odsetkami. Dotacje w części niewykorzystanej do końca roku budżetowego podlegają także zwrotowi ${ }^{44}$.

Największy udział w ogólnej strukturze dotacji celowych (rysunek 5) miały środki przekazane na zadania z zakresu administracji rządowej oraz na zadania własne. Razem stanowiły one w 2010 roku prawie 95\% całości otrzymanej przez gminy dotacji celowej. Pieniądze pochodzące z pozostałych trzech typów dotacji były w budżetach gmin niezbyt pokaźne, a tym samym mniej znaczące dla działania samorządu.

40 P. Swianiewicz, op.cit., s. 88

41 Ustawa z dnia 13 listopada 2003 r. o dochodach jednostek samorządu terytorialnego, op.cit., art. 8 ust. 1.

42 Z. Ofiarski, Subwencje i dotacje jednostek samorządu terytorialnego, Difin, Warszawa 2002, s. 24.

43 L. Patrzałek, op.cit., s. 224.

${ }_{44}$ Ustawa z dnia 27 sierpnia 2009 r. o finansach publicznych (DzU nr 157 poz. 1240 z późn. zm.), art. 168 ust. 1 i art. 169 ust. 1. 
Rysunek 5. Struktura otrzymanych przez gminy dotacji celowych w 2010 roku (w \%)

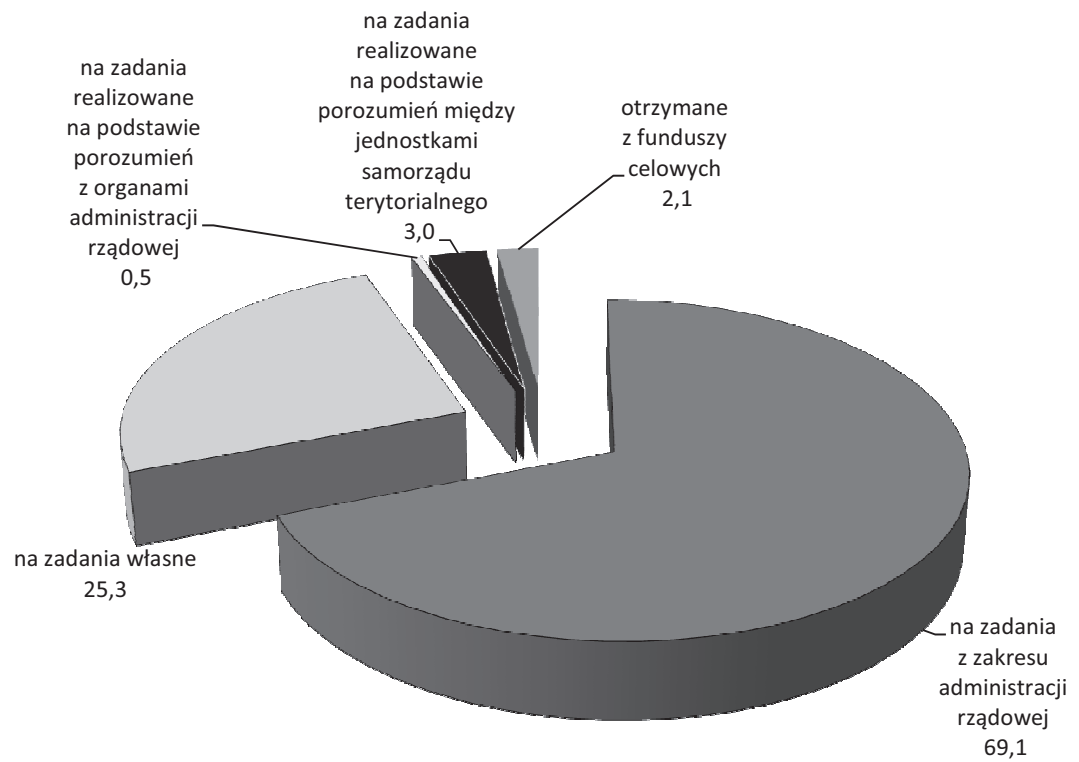

Źródło: Opracowanie własne na podstawie danych ze strony internetowej Ministerstwa Finansów: http:// www.mf.gov.pl/_files_/finanse_samorzadow/sprawozdania_budzetowe/2010/2010kw4/gminy_ivkw10_dw.xls (8.01.2012).

Samorządy gminne mogą ubiegać się o różne typy dotacji celowych ${ }^{45}$, których konstrukcja i zasady funkcjonowania nie są jednolite. Podmiotem przekazującym środki w głównej mierze jest budżet państwa, ale obowiązujące rozwiązania prawne przewidują też możliwość uzyskiwania dotacji, np. z funduszy celowych lub budżetów innych jednostek samorządu terytorialnego. Gminy mają więc możliwość aktywnego poszukiwania renty, starając się o środki finansowe przyznawane przez różne podmioty dotujące.

Gmina wykonująca zadania zlecone z zakresu administracji rządowej oraz inne zadania zlecone ustawami otrzymuje z budżetu państwa dotacje celowe w wysokości zapewniającej ich realizację. Wielkość kwoty dotacji celowej jest tu ustalana zgodnie z zasadami przyjętymi w budżecie państwa do określania wydatków podobnego rodzaju. Przekazane dotacje powinny umożliwiać pełne i terminowe wykonanie zlecanych zadań. Gmina może wykonywać także zadania z zakresu administracji rządowej na mocy zawartego porozumienia - wówczas otrzymuje dotację celową w kwocie wynikającej z podpisanego dokumentu.

45 Ustawa z dnia 13 listopada 2003 r. o dochodach jednostek samorządu terytorialnego, op.cit., art. $42-51$. 
Dotacja celowa na zadania zlecone $\mathrm{z}$ zakresu administracji rządowej oraz inne zadania zlecone ustawami jest próbą: odrzucenia uznaniowości w przyznawaniu środków oraz wypracowania obiektywnych kryteriów ustalania kwot. Przesłanki przyznawania pieniędzy nie są jednak wystarczająco precyzyjne i mogą stanowić źródło sporów między poszczególnymi typami samorządów ${ }^{46}$. Tak więc w odniesieniu do najbardziej obiektywnego typu dotacji celowych będzie istniała także możliwość pogoni za rentą, na rzecz uzyskania jak najlepszych warunków działania zainteresowanych jednostek.

Dotacje celowe $\mathrm{z}$ budżetu państwa na dofinansowanie zadań własnych nie mogą przekroczyć $80 \%$ kosztów wykonania zadania ${ }^{47}$. Dotacje te mogą dotyczyć działań z zakresu zadań inwestycyjnych szkół i placówek oświatowych (w tym przypadku maksymalny poziom wsparcia wynosi połowę planowanych wydatków gminy na realizację danego przedsięwzięcia). Dotacje celowe na zadania własne mogą być związane m.in. z wdrażaniem reformy systemu oświaty, inicjatywami wspierania edukacji na obszarach wiejskich, wyrównywaniem szans edukacyjnych oraz zapewnianiem kształcenia praktycznego. Przyznawane środki mogą także służyć budowie i remontom obiektów sportowych oraz rozwijaniu sportu przede wszystkim wśród dzieci, młodzieży oraz osób niepełnosprawnych. Dotacje celowe na zadania własne pozwalają również na budowę, przebudowę oraz remont dróg gminnych. Samorządom gminnym przysługuje ponadto możliwość ubiegania się o dotacje z budżetu państwa na dofinansowanie zadań własnych objętych kontraktem wojewódzkim.

Gmina realizująca zadania z zakresu działania innych jednostek samorządu terytorialnego na podstawie zawartych porozumień otrzymuje od tych jednostek dotacje celowe w kwocie wynikającej z podpisanego dokumentu. Sama gmina może również udzielać dotacji innym jednostkom samorządu terytorialnego na dofinansowanie realizowanych przez nie zadań, a także pozyskiwać pieniądze w ramach dotacji $\mathrm{z}$ funduszy celowych.

Analizując dane zamieszczone w tabeli 2, widać, iż od 2009 roku pojawia się kategoria „dotacje ogółem” - obejmuje ona oprócz dotacji celowych także kolejne ich typy. Specyficzną formą dotacji dla jednostek samorządu terytorialnego były dotacje rozwojowe, które występowały w budżetach gmin w 2009 roku i stanowiły wówczas prawie $10 \%$ ogółu przyznanych im dotacji. Były one przeznaczane na finansowanie krajowych oraz regionalnych programów operacyjnych. Od 2010 roku natomiast istnieje budżet środków europejskich, który zawiera środki na finansowanie programów

46 A. Hanusz, A. Niezgoda, P. Czerski, Dochody budżetu jednostek samorzadu terytorialnego, Oficyna Wolters Kluwer, Warszawa 2009, s. 246.

47 Ustawa z dnia 27 sierpnia 2009 r. o finansach publicznych, op.cit., art. 128 ust. 2. 
operacyjnych ${ }^{48}$. Przeważające w strukturze dotacji ogółem są cały czas dotacje celowe. Są one oceniane negatywnie ze względu na ich celowy charakter.

Uznaniowość przekazywania środków w ramach dotacji celowych ${ }^{49}$ zaburza jasność przyznawania pieniędzy w ramach tego transferu. Można więc wówczas mówić o gminach „uprzywilejowanych" w otrzymywaniu funduszy oraz o gminach „pokrzywdzonych” takim podziałem. Brak jasnych kryteriów uzyskiwania przez samorząd transferów narusza ład moralny stanowiący fundament funkcjonowania każdego społeczeństwa ${ }^{50}$. Dodatkowo uznaniowy charakter dotacji powoduje, że mogą być one traktowane przez państwo jako finansowy instrument wpływania na gminy w celu zrealizowania określonej polityki ${ }^{51}$.

Przedstawiona charakterystyka dotacji celowych umożliwia występowanie tu aktywnego poszukiwania renty przez gminy. Brak przejrzystych kryteriów przyznawania tych dochodów uzupełniających powoduje dążenie samorządów gminnych do kształtowania takich relacji z podmiotem dotującym, aby uzyskiwać jak największe wsparcie finansowe. To oznacza, że dotowane wcale nie muszą być gminy najbardziej potrzebujące tych środków, tylko te, które umiały się o nie postarać.

\section{Zakończenie}

W ustrojach demokratycznych państwo ma zajmować się realizacją interesów ogólnospołecznych, powinny mu w tym pomagać jednostki samorządu terytorialnego. Gminy, poprzez swoją działalność, mają przyczyniać się do poprawy warunków życia mieszkańców oraz podejmować kroki zmierzające do rozwoju społeczno-gospodarczego jednostki. Te cele mogą właściwie urzeczywistniać, jeśli dysponują odpowiednimi środkami finansowymi.

Subwencje ogólne oraz dotacje celowe to, wraz z dochodami własnymi, konstytucyjnie zagwarantowane typy dochodów gmin. Są one także narzędziami realizacji dwóch funkcji finansów publicznych - alokacyjnej i redystrybucyjnej. Stanowią łącznie ponad połowę dochodów budżetów gmin w naszym kraju, są więc

\footnotetext{
${ }^{48}$ E. Suchocka-Roguska, Dochody jednostek samorzadu terytorialnego, w: Finanse publiczne a kryzys ekonomiczny, red. A. Alińska, B. Pietrzak, CeDeWu, Warszawa 2011, s. 119.

49 W najmniejszym zakresie dotyczy ona dotacji na: zadania zlecone z zakresu administracji rządowej oraz inne zadania zlecone ustawami, ale nadal tu występuje.

50 S. Sztaba, Aktywne poszukiwanie..., op.cit., s. 147.

51 A. Hanusz, A. Niezgoda, P. Czerski, op.cit., s. 242.
} 
znaczącym źródłem finansowania potrzeb wydatkowych tych jednostek samorządu terytorialnego.

Dochody uzupełniające mają przyczyniać się do istnienia podobnych warunków zaspokajania podstawowych potrzeb ludności w skali całego kraju. Znaczący ich udział w budżetach gmin zmniejsza swobodę podejmowanych tam działań oraz kształtuje taki system relacji z państwem, który cechuje się niepewnością w aspekcie wysokości przekazywanych samorządom gminnym środków. Buduje także brak finansowego poczucia bezpieczeństwa gmin w odniesieniu do trwałości istniejących zasad podziału pieniędzy.

Podsumowując, należy stwierdzić, że samorządy gminne aktywnie poszukują renty w zakresie dochodów uzupełniających. Widoczne jest dążenie tych jednostek samorządu terytorialnego do posiadania możliwie największych funduszy. Przejawy takiej działalności można obserwować zarówno na etapie kształtowania rozwiązań prawnych dotyczących funkcjonowania dochodów uzupełniających budżety gmin, jak i w samej procedurze pozyskiwania tych środków. Potrzebne są więc zmiany prawa, aby uzyskać takie regulacje, które nie pozwalają na uznaniowe przekazywanie środków z budżetu państwa na rzecz jednostek samorządu terytorialnego. Należy tworzyć obiektywne i jasne kryteria przekazywania transferów. Mierzalne i dokładnie określone przesłanki przyznawania środków ograniczą aktywne poszukiwanie renty przez samorządy gminne. Przyczynią się jednocześnie do systematycznych działań władzy lokalnej zmierzających do poprawy warunków życia mieszkańców oraz rozwoju społeczno-gospodarczego jednostki.

\section{Supplementary income of communal budgets in the light of rent seeking}

Communes are units of territorial self-government responsible for carrying out the most public services, for which purpose they need to seek sufficient funds. The income of communal self-governments consists in: own income, general subsidies and targeted grants from the state treasury. Supplementary income of communal budgets includes funds other than own income. Communal budgets are tied to the central budget by transfer of funds through general subsidies and targeted grants. The substantial share of supplementary income within the total income structure makes communes dependent on the state. The need for self-governments to obtain other sources of income opens up a rent-seeking possibility for communes. These territorial units of self-government become interest groups striving to achieve the best possible conditions for their own functioning. 
The aim of this paper is to answer the question whether communal self-governments engage in rent-seeking as regards supplementary income.

The paper describes the specificity of supplementary income in Polish communal budgets, their functioning including appropriate legal regulations, and their application in practice. General subsidies and targeted grants from the state treasury are also characterized. The paper also analyses the relative shares of the two types of supplementary income in the communal budget structure and presents the resulting conclusions.

The structure of the paper and the analysis contained herein have mandated the conclusion that communal self-governments engage in rent-seeking as regards supplementary income.

\section{Les revenus supplémentaires dans les budgets des communes à la lumière de la recherche de rente}

Les communes sont des unités gouvernementales locales, qui effectuent la plupart des tâches publiques. Elles doivent donc trouver des fonds suffisants pour leur exécution. Les revenus des gouvernements locaux sont les recettes propres, les subventions générales et les subventions ciblées provenant du budget de l'État. Les revenus supplémentaires des budgets communaux comprennent les fonds financiers, qui nappartiennent pas à la catégorie de leurs revenus propres. Les budgets locaux sont liés au budget central à travers le transfert de fonds dans le cadre des subventions générales et ciblées. Une part importante des revenus supplémentaires dans la structure totale de revenus entraîne une forte dépendance des communes de l'État. La nécessité d’avoir de multiples sources de revenus provoque la situation dans laquelle les communes sont à la recherche de rente. Les unités gouvernementales locales deviennent un groupe d'intérêt qui vise à optimiser les conditions de son fonctionnement. L'objectif de cette étude est de répondre à la question si les collectivités locales sont à la recherche de rente en matière de revenus supplémentaires. Larticle décrit la spécificité de ces revenus dans les budgets communaux en Pologne, il présente leur fonctionnement, en tenant en compte des solutions juridiques dans ce domaine, et il montre leur application dans la pratique. Lauteur caractérise les subventions générales et ciblées du budget de l'État. Il analyse la contribution de deux types de revenus dans la structure des recettes des communes et les conclusions qui en dérivent. La structure de larticle et l'analyse effectuée permettent de constater, que les collectivités locales sont à la recherche de rente en termes des recettes supplémentaires. 